\title{
Matrioszka i idealna rozdzielczość języka. O trudnej sztuce pisania abstraktów
}

adacze często lekceważą abstrakty, nazywając je streszczeniami. Zdarzają się abstrakty bardzo krótkie, niedbałe, bez właściwego oznaczenia tzw. słów kluczowych albo zwłaszcza w przypadku humanistów - bardzo obszerne, zawierające zbędne ozdobniki. Konieczność publikacji w czasopismach indeksowanych w międzynarodowych bazach danych - wprowadzona ostatnimi zmianami w prawie o nauce w Polsce ${ }^{1}$ - wymusza jednak zapoznanie się z podstawami „abstraktologii”. Zmiany w kierunkach rozwoju polskiej nauki widać już w ostatnich ogłoszeniach dotyczących finansowania badań. Wystarczy spojrzeć na najnowsze wytyczne grantodawców, choćby konkurs „OPUS21” Narodowego Centrum Na$\mathrm{uki}^{2}$, w którym wskazane ścieżki publikacyjne rekomendują czasopisma ukazujące się w modelu open access - ścieżka pierwsza to periodyki z wykazu DOAJ, a ścieżka trzecia odsyła do programów publikowania otwartego. Większość z czasopism spełniających kryteria jest indeksowana w bazach danych oczekujących od autorów konkretnych, standaryzowanych metadanych. W tym dobrego abstraktu.

\section{Speleolog - jaskiniolog — badacz jaskiń — jaskiniowiec?}

W kwietniu 2021 roku ukazał się artykuł dwóch młodych biologów z Włoch dotyczący sztuki pisania abstraktów ${ }^{3}$. Alejandro Martínez to biolog ewolucyjny, a Stefano Mammola to ekolog, obaj pracują w National Research Council w Pallanza we Włoszech. Korzystając z Web of Science, platformy internetowej, która umożliwia subskrybentom dostęp do baz danych publikacji naukowych, zebrali i przeanalizowali 21486 artykułów poświęconych badaniu

1 konstytucjadlanauki.gov.pl.

2 www.ncn.gov.pl/ogloszenia/konkursy/opus21.

3 Martínez A., Mammola S., Specialized terminology reduces the number of citations of scientific papers, „Proceedings of the Royal Society B: Biological Sciences” t. 288, nr 1948 (14.04.2021), s. 2020-2581. DOI: 10.1098/ rspb.2020.2581. 


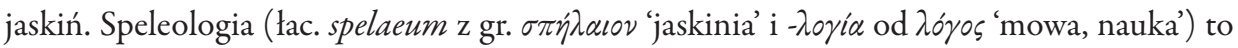
nauka o jaskiniach. Speleolodzy badają takie kwestie, jak geneza i rozwój jaskiń, mikroklimat, stosunki wodne, przyroda ożywiona - flora i fauna itp., interesują ich zagadnienia ochrony środowiska. Jaskinie badane są też w ramach geologii, hydrogeologii, paleontologii, archeologii, turyzmu. Speleolog może także uprawiać sport, rodzaj alpinizmu podziemnego — to już inna historia. Ostatnio jaskinie stały się także miejscem badań nad nietoperzami, które — jak wiadomo - są niezwykle ważne dla wirusologii i epidemiologii. Dlaczego poruszamy ten temat?

Pora na małe doświadczenie mentalne. Przeczytajmy zdanie:

Odwiedziłem dziś dwa ciemne miejsca pod ziemią, w których żyje wiele zwierząt. Today I visited two dark places under ground where many animals live.

Czy to zrozumiałe zdanie? Zostało „wyprodukowane” przy użyciu tysiąca najczęściej stosowanych słów w języku angielskim, potem przetłumaczone na język polski na potrzeby eseju.

Pierwotnie zdanie miało brzmieć:

Byłem dzisiaj w dwóch jaskiniach znanych ze swojej bioróżnorodności. Today I was in two caves known from its biodiversity.

- ale takie zdanie nie jest akceptowane przez program sprawdzający, czy używamy tych właściwych słów, czyli występujących najczęściej, w uzusie ${ }^{4}$.

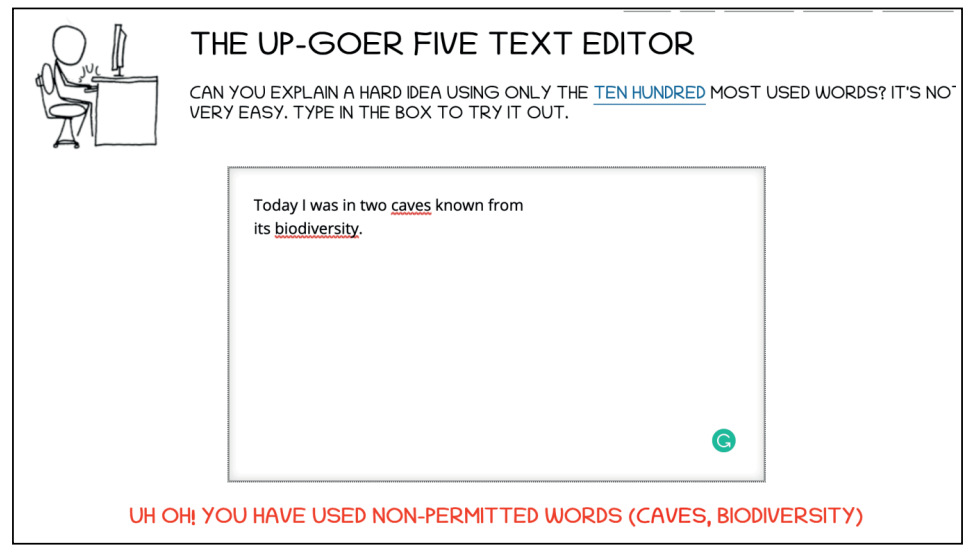

Ryc. 1. Zrzut ekranu komputera z wynikami testu z programem The Up-Goer Five Text Editor (JP)

4 Program jest dostępny bezpłatnie w Internecie: www.ef.edu/english-resources/english-vocabulary/top-1000words/. Program sprawdzający poziom trudności angielskiego tekstu: splasho.com/upgoer5/. Dla tekstów polskich stworzono program działający na podobnej zasadzie: www.jasnopis.pl/. Oczywiście nie są to narzędzia idealne, gdyż chwilami sugerują uproszczenia na granicy absurdu, ale obrazują pewien problem, a mogą też posłużyć zabawie. 
Jak wygląda abstrakt artykułu opublikowanego w międzynarodowym punktowanym czasopiśmie wrzucony do programu?

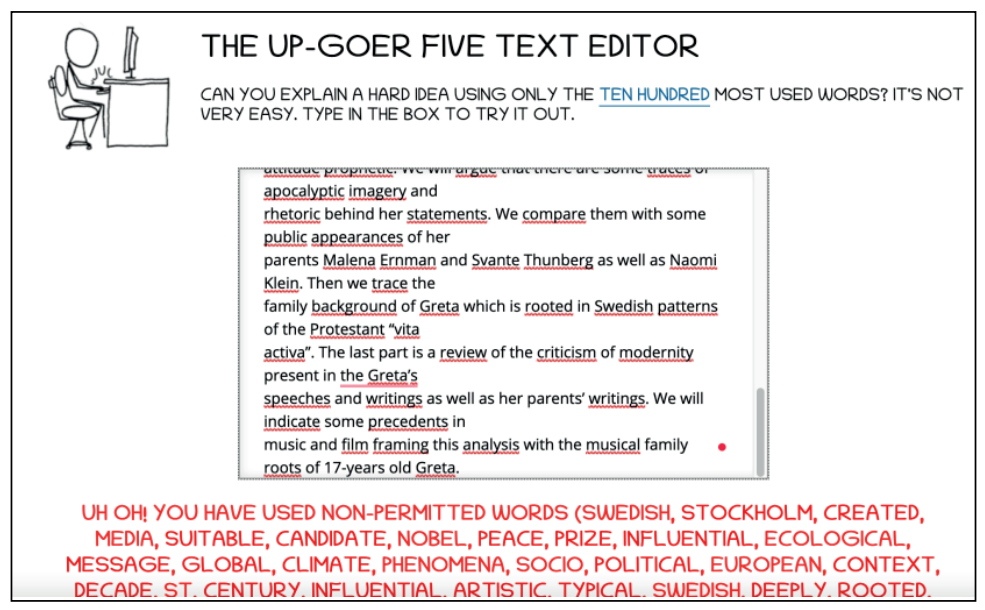

Ryc. 2. Abstrakt artykułu [autor - J.P.] zanalizowany przez The Up-Goer Five Text Editor: splasho.com/upgoer5

A polski przykład?

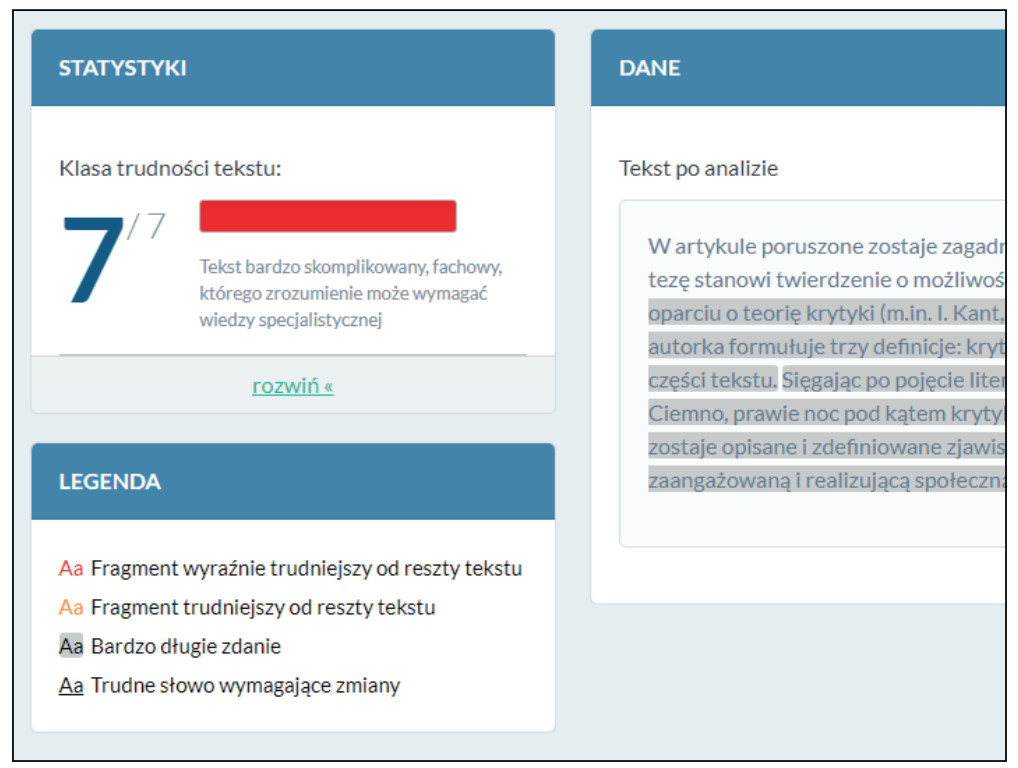

Ryc. 3. Abstrakt artykułu [autorka - A.Z.] zanalizowany przez Jasnopis: www.jasnopis.pl 
Być może wydaje się to zabawne, ale mamy do czynienia z bardzo poważnym problemem naukowym i społecznym. To, jakim językiem się posługujemy, wyraźnie decyduje o wielu sprawach w naszym życiu. W życiu naukowym także. Raczej powszechne jest przekonanie, że im bogatsze słownictwo, tym bogatsze poznanie świata. Słynny przykład z nazwami kolorów bywa często używany, aby wyjaśnić magię słownika: zwykły użytkownik języka, amator, używa na co dzień maksymalnie do dwudziestu nazw kolorów, natomiast plastyk poruszający się na co dzień w obszarach widzialności posługuje się blisko setką nazw kolorów!

Wydawałoby się, że im bardziej szczegółowy ogląd świata, tym bardziej szczegółowy język jest nam potrzebny. A jednak — im bardziej szczegółowego języka używamy, tym mniej komunikatywni się stajemy. I zamykamy się w swoich wieżach z kości słoniowej...

Można byłoby posłużyć się tutaj metaforą dotyczącą rozdzielczości: możliwość zrozumienia i ogarnięcia mentalnego także jest zdeterminowana właściwą rozdzielczością: jeśli jest ona za mała, lekceważymy wiadomość jako mało ekspercką, jeśli zaś jest ona za duża, a tekst przeładowany żargonem i terminologią, wycofujemy się. Jeśli poszukujemy konkretów, giniemy w gąszczu.

Zagadnienie to jest fascynujące w planie indywidualnym, ale jeszcze więcej problemów niesie społeczne życie naukowe. Wiadomo, że im bardziej rozwinięta gałąź wiedzy, tym większy zasób terminologii specjalistycznej, słów i pojęć, które dla większości użytkowników stają się niezrozumiałe. Aparatura pojęciowa już w 1934 roku przez Kazimierza Ajdukiewicza była określana jako rodzaj podstawowego narzędzia decydującego o naszym obrazie świata ${ }^{5}$. Jednak ta sama aparatura, która bywa wielkim odkryciem, dla większości użytkowników jest nic niemówiącym żargonem. Jak zauważają wspomniani na wstępie biolodzy zajmujący się językiem „jaskiniowców”, tzn. inter- i multidyscyplinarnego grona badającego życie jaskiń: „[...] w dobie interdyscyplinarności stosowanie żargonu może utrudniać skuteczną komunikację między naukowcami, którzy nie mają wspólnego zaplecza naukowego”. Włoscy badacze nawiązują do wcześniejszych szwedzkich badań nad „czytelnością” tekstów naukowych ${ }^{6}$. Kult żargonu był krytykowany wielokrotnie, ale najbardziej w artykule Scotta L. Montgomery’ego z $1989 \mathrm{roku}^{7}$.

Martínez i Mammola zbadali związek między używaniem żargonu a cytowalnością. Rzecz jest niezwykle istotna dla naukowców i życia naukowego, zwłaszcza od 2005 roku, kiedy to Jorge E. Hirsch opublikował swój słynny artykuł o mierzeniu wpływu publikacji — od tamtego czasu pisze się i mówi o tzw. indeksie Hirscha $(h \text {-index })^{8}$. Włoscy badacze, biolog ewolucyjny i ekolog, wykorzystali 21486 artykułów „jaskiniowców” (czy mniej dosłownie traktując upraszczanie: „jaskiniologów”). Dyscyplina ta wyjątkowo dobrze nadawała się do badania - często występują w niej różnice językowe między badaczami i to nie tylko wśród tych, którzy reprezentują odmienne dyscypliny naukowe. Martínez i Mammola wyka-

5 Zob. Ajdukiewicz K., Obraz świata i aparatura pojeciowa [w oryginale niem.: Das Weltbild und die Begriffsapparatur], „Erkenntnis”, IV, 1934, s. 259-287.

6 Zob. Plavén-Sigray P., Granville J.M., Schiffler B.Ch., Thompson W.H., The Readability of Scientific Texts is Decreasing Over Time, red. King St., eLife 6 (5.09.2017): e27725. DOI: 10.7554/eLife.27725.

7 Zob. Montgomery S.L., The cult of Jargon: Reflections on language in science, „Science as Culture”, nr 1(6) (1.01.1989), s. 42-77. DOI: 10.1080/09505438909526248.

8 Zob. Hirsch J.E., An Index to Quantify an Individual's Scientific Research Output, „Proceedings of the National Academy of Sciences", nr 102, 46 (15.11.2005), s. 16569-72. DOI: 10.1073/pnas.0507655102. 
zali w konkluzji „istotny negatywny związek między proporcją żargonowych słów w tytule i streszczeniu a liczbą cytowań, jakie otrzymuje artykuł”. Jeśli więc mieć na uwadze, że algorytmy przeszukujące bazy danych oraz realni czytelnicy traktują abstrakty i słowa klucze jako „atraktory”, zrozumiałe staje się wezwanie naukowców do delegowania żargonu do tych tylko fragmentów artykułów, w których jego użycie jest nieuniknione i wyzbycie się nadmiaru terminologii specjalistycznej z abstraktu i słów-kluczy.

Autorzy przywołanej pracy przyznają, że żargon, choć początkowo trudny, skupia lata wiedzy w precyzyjnym obrazie mentalnym, jest esencją przeszłych badań naukowych, skrótem dorobku naukowego poprzedników. Posługują się tutaj metaforą rosyjskiej „matrioszki”: każdy kolejny termin wzbogaca początkową wiadomość o nowe informacje, porządkując i systematyzując koncepcje w korpusie naukowym. W podsumowaniu włoscy badacze stwierdzają, że żargon może co prawda bardzo pomagać w przekazywaniu idei, dzięki kondensacji, ale częściej przyczynia się do podziału na sztucznie zdefiniowanych „znawców” oraz „amatorów", wzmacniając tym samym izolację naukowców w ich — znanych z literatury krytyków świata akademickiego — wieżach z kości słoniowej.

\section{Idealna rozdzielczość}

Z powyższych rozważań można wysnuć wniosek, że żargonu zasadniczo należy unikać, jednak byłby to wniosek błędny: w abstrakcie, który nie jest przecież zwykłym streszczeniem, trzeba osiągnąć odpowiednią rozdzielczość percepcyjną wirtualnego czytelnika. Błędnie brzmi zatem część definicji z Wikipedii:

Abstrakt — streszczen i e publikacji naukowej lub książki, w którym w formie maksymalnie skondensowanej, z jak największą liczbą słów kluczow y ch, zawarte są podstawowe informacje o tezie artykułu, metodyce

przeprowadzonych badań, najważniejszych wynikach oraz wnioskach ${ }^{9}$.

$$
\text { [podkreślenie - J.P.] }
$$

W tym kontekście abstrakt to ani nie po prostu streszczenie, ani nie maksymalna kondensacja z jak największą liczbą słów. Co więcej, według Martíneza i Mammoli, pojawia się także inny wniosek: w abstraktach osiągnąć należy odpowiednią rozdzielczość percepcyjną terminologii specjalistycznej, jeśli piszemy artykuł, który potem indeksowany jest w bazach. Natomiast jeśli aplikujemy o granty, lepiej być jak najbardziej eksperckim: najwięcej sukcesów miały zawsze te aplikacje grantowe, które były najeżone żargonem. Publicznie dostępne abstrakty czytają w końcu jedynie chętni, którzy sami po nie sięgną, zaś abstrakty grantowe są oceniane przez wąską grupę specjalistów — oceniają je oni, umieszczając w szerszej perspektywie wiedzy stricte specjalistycznej.

Idealna rozdzielczość w artykułach naukowych nie może być tą samą rozdzielczością, która byłaby wymagana z punktu widzenia popularyzatorów nauki. Nasycenie terminologią specjalistyczną jest przecież stopniowalne...

9 pl.wikipedia.org/wiki/Abstrakt. 


\section{SZYBKI KURS PISANIA ABSTRAKTó ${ }^{10}$}

Abstrakt, jakiego oczekują dziś czasopisma i wydawnictwa naukowe, powinien być czymś więcej niż tylko kilkoma zdaniami na temat publikacji czy tradycyjnym "streszczeniem”. Dłuższych abstraktów (lecz niezbyt długich!) o uporządkowanej strukturze wymagają bowiem bazy danych, dla których istotne jest dobre indeksowanie tekstu. A dobre indeksowanie tekstu naukowego oznacza to samo, co pozycjonowanie w wyszukiwarkach dla branży $\mathrm{SEO}^{11}$ - to nie uprzedmiotowienie ani komercjalizacja nauki, to nieunikniony postęp. Warto zdawać sobie sprawę, że abstraktu artykułu nie piszemy już tylko dla „żywego” czytelnika ani tym bardziej tylko dla eksperta w naszej dziedzinie (chyba że aplikujemy o grant).

Styl APA (American Psychological Association), stawiany często za wzór dla badaczy, zawiera również wskazówki odnoszące się do konstruowania abstraktu ${ }^{12}$. Przede wszystkim należy traktować go jako podsumowanie artykułu obejmujące problem badawczy, nasze hipotezy, metody i wyniki badań, nie jak streszczenie. Co radzą specjaliści?

Rekomendowana długość abstraktu wynosi ok. 250 słów (tutaj różne redakcje mogą się nieco różnić między sobą). Zwykle nie określa się minimalnej liczby znaków, jednak warto, by abstrakt miał co najmniej 200 słów (choć w stylu APA mowa jest o min. 150 wyrazach) pozwala to zawrzeć więcej słów i fraz kluczowych, przeszukiwanych przez bazy danych. Abstrakty mające od 200 do 300 słów rekomenduje redakcjom czasopism choćby baza Scopus. Dla abstraktów w języku polskim często podaje się objętość w liczbie znaków ze spacjami (zzs) - abstraktowi angielskiemu liczącemu ok. 250 słów będzie odpowiadał polski abstrakt o objętości ok. 1600-1800 zzs.

Formatowanie tekstu może być wyraźnie określone przez redakcję lub wydawcę, a jeżeli nie jest, warto się trzymać standardów: marginesy ustawione na $1 \mathrm{cal}(2,54 \mathrm{~cm})$, pogrubiony nagłówek, użycie czytelnej czcionki (np. Times New Roman 12), nieprzekraczanie limitu 200-250 słów. Do abstraktu należy dołączyć oddzielne słow a kl u c z o w e — najczęściej od trzech do pięciu. Są one używane przez bazy danych do indeksowania i pozwalają innym łatwo odnaleźć naszą publikację, dlatego warto wybrać słowa najlepiej odnoszące się do badań, o których piszemy.

Abstrakt stanowi samodzielny tekst, który dołączony do publikacji informuje czytelnika o zawartości samego artykułu lub książki. Najlepiej zatem sprawdzić go i przemyśleć po zakończeniu pracy z publikacją, gdy znamy już wszystkie wnioski. Warto zadbać o uporządkowanie treści abstraktu. W tym celu można wykorzystać przykładowe pytania i odpowiedzieć na nie jednym/dwoma zdaniami, nie nadużywając żargonu:

- Jakie jest główne zagadnienie poruszane w pracy? - zarysuj cel badań, pytania, tezy lub hipotezy;

- Jakie badania zostały przeprowadzone? - wyjaśnij metody badawcze;

- Co ustalono dzięki badaniom? - podsumuj najważniejsze ustalenia/efekty;

- Jakie wnioski można wysnuć z badań? - przedstaw interpretację.

10 Ostatnia - praktyczna - część eseju ukazała się również w skondensowanej formie jako materiały opracowane dla Biblioteki Uniwersytetu Łódzkiego.

11 Search Engine Optimization. Warto wiedzieć, że istnieje również ASEO, czyli Academic Search Engine Optimization — openjournalsystems.com/academic-search-engine-optimization. 


\section{Cele badawcze}

Zacznij od jasnego określenia problemu badawczego. Jaki problem praktyczny lub teoretyczny rozwiązują Twoje badania? Na jakie pytania odpowiadasz? Określ cel swoich badań. Używaj słów opisujących czynności, jakie wykonywałeś/wykonywałaś, prowadząc badania, np. „analizuję”, „sprawdzam”, „badam”. Możesz używać czasu teraźniejszego lub przeszłego, ale raczej nie przyszłego - odnosimy się do badań, które już zostały przeprowadzone. Zamiast napisać więc: „To badanie ma na celu sprawdzenie zależności między...” — napisz: „To badanie sprawdza zależności między.... Można dodać krótką informację o kontekście badań, społecznym bądź naukowym, ale bez wchodzenia w szczegóły.

\section{Metodologia}

Wskaż metody badawcze zastosowane w badaniach. Najlepiej, by ta część mieściła się w jednym czy dwóch zdaniach. Można zastosować czas przeszły, ponieważ czynności zostały już wykonane np. „Ankietę przeprowadzono wśród pracowników i studentów...”. Nie dokonuj oceny metodologii — w abstrakcie mamy tylko zapoznać z nią czytelnika.

\section{Wyniki badań}

Podsumuj główne wyniki badań. Możesz używać czasu teraźniejszego lub przeszłego, np. „Analiza wykazała, że...”, „Testy dowodzą.... Nie musisz uwzględniać w abstrakcie wszystkich wyników badań, które bywają przecież złożone. Wystarczy, że podkreślisz najważniejsze ustalenia zaznajamiające czytelnika z danymi badaniami.

\section{Wnioski, podsumowanie}

Na koniec przedstaw główne wnioski, jakie można wysnuć z twoich badań. Czy i jak udało ci się odpowiedzieć na postawione pytanie/osiągnąć cel badawczy? Jeżeli istnieją znaczące ograniczenia w zakresie twoich badań lub badania wymagają kontynuacji, wspomnij o tym.

Unikaj cytowania źródeł w abstrakcie! Abstrakt powinien być całkowicie zrozumiały bez odwoływania się do innych źródeł. Odnośniki w abstraktach mogą znaleźć się tylko w wyjątkowych sytuacjach, np. gdy artykuł jest odpowiedzią na inny artykuł lub bezpośrednio nawiązuje do innych badań i bez kontekstu byłby niezrozumiały.

Warto pamiętać, że najistotniejszy obecnie jest abstrakt w języku angielskim i należy zwracać uwagę na poprawność gramatyczną, np. stosowanie odpowiedniego czasu przeszłego. Jeżeli nie jesteś pewien poprawności tekstu, zawsze warto skonsultować się z profesjonalistą lub poczytać inne abstrakty ze swojej dyscypliny. Abstrakt w języku angielskim jest bardzo ważny, nawet jeżeli piszesz po polsku lub w innym języku — obecnie rozwój technologii pozwala na natychmiastowy przekład maszynowy z nawet najbardziej egzotycznego dla użytkownika języka obcego, ale to właśnie abstrakt musi zachęcić potencjalnego czytelnika, by zdobył się na wysiłek poznania całości.

\section{Jak więc napisać dobry abstrakt?}

1. Nie pisz streszczenia, napisz abstrakt!

2. Pisząc abstrakt artykułu indeksowanego w bazach danych w otwartym dostępie, zastanów się nad nasyceniem terminologią i ogranicz ją do niezbędnego minimum. 
3. Pisząc artykuł, nie unikaj specjalistycznego języka, ale ogranicz go do miejsc niezbędnych. W abstrakcie staraj się unikać żargonu.

4. Aplikując o granty, pisz projekt i abstrakty językiem specjalistycznym: piszesz je dla wysoko ocenianych przez środowisko specjalistów, nie dla laików.

5. Jeśli mówisz do ludzi, mów ich językiem — najlepiej najprostszymi, najczęściej używanymi słowami.

JAROSŁAW PŁUCIENNIK

https://orcid.org/0000-0001-6984-7734

Profesor zwyczajny nauk humanistycznych, kulturoznawca, literaturoznawca, kognitywista. Jest afiliowany na Uniwersytecie Łódzkim, Instytut Kultury Współczesnej, Katedra Teorii Literatury - ul. Pomorska 171/173, 90-236 Łódź. Redaktor naczelny „Zagadnień Rodzajów Literackich”. Byly prorektor Uniwersytetu Łódzkiego.

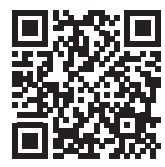

Kontakt: jaroslaw.pluciennik@uni.lodz.pl

AnNA Zatora

(iD) https://orcid.org/0000-0003-4597-5568

Doktor nauk humanistycznych, literaturoznawczyni, redaktorka „Zagadnień Rodzajów Literackich". Pracuje w Oddziale Informacji Naukowej i Analiz Bibliometrycznych Biblioteki Uniwersytetu Łódzkiego - ul. Jana Matejki 32/38, 90-237 Łódź.

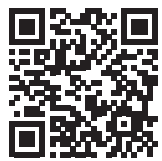

Kontakt: anna.zatora@lib.uni.lodz.pl 
Powyższy tekst nie jest artykułem naukowym. Jak mógłby jednak wyglądać abstrakt takiego artykułu?

\begin{tabular}{|l|c|}
\hline Abstrakt & Nagłówek \\
\hline $\begin{array}{l}\text { W artykule badamy konieczność dostosowania abstraktu artykułu lub } \\
\text { innego tekstu naukowego do odbiorcy i sposobu indeksowania treści } \\
\text { naukowych przez wyszukiwarki naukowe oraz bazy danych. Stawiamy } \\
\text { tezę, że abstrakt nie jest tym samym co streszczenie i musi mieć określony } \\
\text { kształt oraz że duży wpływ na widoczność tekstu w sieci ma stopień } \\
\text { użycia terminologii specjalistycznej. }\end{array}$ & $\begin{array}{c}\text { Określenie } \\
\text { celu badawczego i tezy }\end{array}$ \\
\hline $\begin{array}{l}\text { Rozwój komunikacji naukowej i publikowanie w modelu open access } \\
\text { sprawia, że autorzy powinni opanować podstawy abstraktologii. } \\
\begin{array}{l}\text { Oczekują tego od nich agencje finansujące badania, instytucje naukowe, } \\
\text { ośrodki badawcze oraz społeczeństwo. Upowszechnianie i popularyzacja } \\
\text { nauki wiążą się z widocznością wyników badań, a także z rozwojem } \\
\text { sztuki pisania abstraktów. }\end{array}\end{array}$ & Kontekst badań \\
\hline $\begin{array}{l}\text { Badanie zostało oparte na doświadczeniach autorów, obserwacji środowi- } \\
\text { ska naukowego oraz dostępnych tekstach dotyczących żargonu/termino- } \\
\text { logii naukowej, metod pisania abstraktów i technik ASEO. }\end{array}$ & Metodologia \\
\hline $\begin{array}{l}\text { Analiza wykazała, że abstrakt tekstu naukowego jest lepiej indeksowany } \\
\text { przez bazy i wyszukiwarki naukowe, gdy zawiera kluczowe słowa i frazy, } \\
\text { oraz że abstrakt napisany językiem zrozumiałym dla odbiorcy jest czytany } \\
\text { chętniej i pomaga upowszechnić tezy zawarte w artykule. }\end{array}$ & Wyniki badań \\
\hline $\begin{array}{l}\text { Wynika z tego, że abstrakt powinien być napisany zgodnie z możliwościa- } \\
\text { mi i ograniczeniami narzędzi indeksujących teksty naukowe oraz dopa- } \\
\text { sowany do odbiorcy w zależności od jego kompetencji: inaczej napiszemy } \\
\text { abstrakt dla ekspertów oceniających granty naukowe, a inaczej gdy ma } \\
\text { popularyzować naukę poza środowiskiem akademickim. Terminologia } \\
\text { powinna być stosowana z umiarem. W abstrakcie warto powtarzać słowa } \\
\text { kluczowe dla samego artykułu, ale bez nadużywania żargonu. }\end{array}$ & Wnioski \\
\hline $\begin{array}{l}\text { Słowa kluczowe: abstrakt, abstraktologia, styl naukowy, ASEO } \\
\text { Sluczowe }\end{array}$ & \\
\hline
\end{tabular}

